\title{
Evaluation of High Yielding Strains of Agaricus bisporus (Lange) Sing
}

\author{
Suresh Kumar ${ }^{1}$, Anila Doshi ${ }^{1}$, Dinesh Kumar ${ }^{2}$ and Kuldeep Singh ${ }^{3 *}$ \\ ${ }^{1}$ Department of Plant Pathology, Rajasthan College of Agriculture, MPUAT, Udaipur, India \\ ${ }^{2}$ Department of Plant Pathology, Rajasthan Agriculture College, SKRAU, Bikaner, India \\ ${ }^{3}$ Department of Plant Pathology, Agricultural Research Station, Sriganganagar, India \\ *Corresponding author:
}

A B S T R A C T

\section{Keywords}

Agaricus bisporus, mushroom yield,

Portbella, A-15, U-3, Delta,

NCS-459.

Article Info

Accepted:

17 April 2017

Available Online:

10 May 2017
The studies of growth behavior and yield potential of different strains (U-3, Delta, A-15, NCS-459, NCS-465 and Portbella) were tested. Among various strains of Agaricus bisporus, U-3 produced maximum mushroom yield (1246.40 gm per 8 $\mathrm{kg}$ of compost) as compared to A-15, Delta, NCS-459, NCS-465 and Portbella strains and maximum number of fruit bodies were produced in strains NCS-465 (128) whereas minimum fruit body was observed in Portbella (96). The average fruiting body weight was observed to be significantly higher in case of strain Portbella $(12.00 \mathrm{gm})$. In the growth behavior, U-3 gave the best performance followed by the other strains. Maximum average length, width of stalk and average width, length of cap was observed in Portbella followed by A-15, U-3, Delta, NCS-459 and minimum was observed in NCS-465.

\section{Introduction}

Agaricus bisporus commonly known as white button mushroom is an edible fungus belongs to phylum Basidiomycota. Mushrooms are the health food of the world. The indoor cultivation of Agaricus bisporus was however started in caves in France around 1810 Vijay and Gupta (1995). It was first cultivated in India more than 3 decades ago, at Chambaghat, Solan.

In India, mushroom cultivation has great potential due to favorable weather conditions, abundant cheaper agro wastes as well as cheaper availability of labour. Now a day's mushroom cultivation has been adopted by progressive farmers as a cottage industry, which not only provides them an additional source of income but they could also recycle the farm waste which was earlier sold by them at much low cost.

Agaricus bisporus is one of the most acceptable edible fungi contributing $31.8 \%$ of total world mushroom production Chang and Miles (2004). The three major mushroom producing countries are China, USA and Netherland which account for more than 60 per cent of the world production. Punjab has become one of leading states in white button mushroom production with 58000 tons/annum Singh et al., (2011). 


\section{Materials and Methods}

\section{Culture}

The parent culture of six strains of Agaricus bisporus (Lange) Sing. viz., U-3, Delta, NCS459, NCS-465, A-15 and Portobella were obtained from All India Coordinated Mushroom Improvement Project, Department of Plant Pathology, R.C.A., Udaipur.

\section{Preparation of spawn}

Spawn was prepared in $500 \mathrm{ml}$ milk bottles. One kilogram healthy wheat grains were dipped overnight and then boiled in 2 liters of water up to semi cooked condition. After boiling, excess of water was decanted off. Then grains were allowed to surface dry by spreading on bloating sheet for an hour. These seeds were then mixed with gypsum (calcium sulphate: $\mathrm{CaSO}_{4}$ ) 2\% and lime (calcium carbonate: $\left.\mathrm{CaCO}_{3}\right) 4.0 \%$ on grain weight basis to adjust the $\mathrm{pH}$ of grains at 7.0-7.8 and to check the coagulation of the grains. About 250 gram grains were filled in each $500 \mathrm{ml}$ milk bottle, plugged tightly and sterilized at $22 \mathrm{lb}$ p.s.i. pressure $\left(126.5^{\circ} \mathrm{C}\right)$ for 2 hours. After cooling each bottle was inoculated with mycelial bits of mushroom culture and then incubated at $23 \pm 2^{0} \mathrm{C}$ in incubator till adequate growth was obtained.

\section{Compost preparation}

Agaricus bisporus (Lange) Sing. require a selective medium for its growth, therefore, synthetic compost was prepared by long method of composting according to formula given by Garcha and Kiran (1981).

$\begin{array}{lll}\text { Wheat straw } & - & 1000 \mathrm{~kg} \\ \text { Wheat bran } & - & 150 \mathrm{~kg} \\ \text { Urea } & - & 18 \mathrm{~kg} \\ \text { Gypsum } & - & 35 \mathrm{~kg}\end{array}$

Wheat straw was spread over the cemented platform. Water was sprinkled over the straw by pipe and frequently turned by forks till sufficient moisture was absorbed. Wetting of straw was continued up to 48 hours. After two days, required quantities of different materials viz., urea and wheat bran except gypsum were thoroughly moistened with water and heap was made. The prepared mixture was filled in the rectangular blocks (moulds). While filling the blocks materials were slightly pressed on the sides and kept loose in the centre. The compost was decomposed by total seven turning and each turning was done at 3 days interval. Gypsum was mixed during $3^{\text {rd }}$ turning and at each turning, water should be sprinkled to make up the loss of moisture content due to evaporation.

\section{Addition of spawn and filling of compost}

On 28th day, the pile was completely broken and the compost was made to cool down. Grain spawn was thoroughly mixed at the rate of 1.0 per cent of the total weight of compost. After spawning, eight $\mathrm{kg}$ of compost was filled in each bag and bags were folded. Then these bags were kept in cropping room having a room temperature of $22 \pm 2^{\circ} \mathrm{C}$ (less than $25^{\circ} \mathrm{C}$ ) and R.H. 85-90\%.

\section{Casing}

A layer of casing material is necessary for inducing fructification in the spawn run compost. A mixture of F.Y.M. and two year old spent compost (1:1) was used as the casing material. After complete the spawn run, casing layer of $4 \mathrm{~cm}$ was applied on the fully spawn run compost after pressing it.

\section{Harvesting}

When the cap diameter of mushroom attained a size of 3-6 cm, these were harvested with clean hands by twisting method and were collected in clean containers. After harvesting, refilling of casing was done by casing material. 


\section{Results and Discussion}

\section{Growth behavior of different strains of the Agaricus bisporus (Lange) Sing}

The results presented in table 1 revealed that the studies of growth behavior of different strains (U-3, NCS 459, NCS-456, A-15, Delta and Portbella) of Agaricus bisporus. The number of days taken for spawn run periods were minimum (14 days) in NCS-465 followed by 15 days ( U-3 and Portbella ) and 16 days (Delta), further maximum number of days taken in NCS-459 and A-15 (17days). Whereas case run and pinhead formation was observed early in strain U-3 (13 and 15 days) in comparison of other strains, the harvesting of $1^{\text {st }}, 2^{\text {nd }}$ and $3^{\text {rd }}$ flushes were early completed (18, 28 and 37 days) from strain U-3 followed by strains Delta, Portbella, NCS-465 and A15 whereas $1^{\text {st }}$ and $2^{\text {nd }}$ flushes were late completed (24 and 33 days) in strain NCS459. The harvesting of $3^{\text {rd }}$ flushes was late completed (43 days) in strain A-15.

This investigation is confirmative with finding of Pal et al., (2006) have also been evaluated different strains of white button mushroom for yield. The best CM-1 strains of Agaricus bisporus were found the best. It gave quicker spawn run, and pinhead initiation and also produced higher number of fruit bodies as well as yield in comparison to other strains (CM-2, CM-3, CM-4 and CM-5). The yield of Agaricus bisporus was significantly higher in steam sterilized casing soil than Formalin and Bavistin. Thick casing layer was found most suitable to obtain higher yield of Agaricus bisporus.

Evaluation of high yielding strains of Agaricus bisporus (Lange) Sing

An experiment was carried out for six strains of Agaricus bisporus were evaluated for yield performance given in table 2 . The highest yield were obtained from strain U-3 with an average $1246.40 \mathrm{gm} / 8 \mathrm{~kg}$ of compost followed by NCS-459 (1216 gm) further other strains NCS-465 (1184 gm), A-15 (1160 gm), Portbella (1150 gm) and Delta (1140 gm) gave minimum yield over all strains. Maximum number of fruiting body were produced in NCS-465 with an average 128 per eight kilogram of compost followed by strain Delta, A-15, and NCS-459 (120), U-3 (115) however minimum number of fruiting body was produced in Portbella with an average of 96 per 8 kilogram of compost. The average fruiting body weight was observed to be significantly higher in case of strain Portbella with an average fruit body weight of $12.00 \mathrm{gm}$ followed by U-3 (10.83 gm), NCS459 (10.13 gm), A-15 (9.66 gm), Delta (9.34gm) and NCS-465 (9.25gm).

The present study showed that confirmative results with finding of Kushwaha et al., (2006) had been observed yield potential of different six strains of Agaricus bisporus (S649, S-46, U-3, Pant-52, and Pant-215) were evaluated for yield performance in terms of the number and weight of fruiting bodies at room temperature. The highest number of fruiting bodies (2161/100kg of compost) was recorded for U-3 followed by S-649 and Pant -215 .

\section{Morphological characteristics of different strains of Agaricus bisporus (Lange) Sing}

Morphological characteristics of different strains were given in table 3 that maximum average length of stalk was observed in Portbella $(3.5 \mathrm{~cm})$ followed by A-15 $(3.2 \mathrm{~cm})$, U-3 $(2.8 \mathrm{~cm})$, Delta $(2.4 \mathrm{~cm})$, NCS-459 (2.2 $\mathrm{cm}$ ), and minimum average length of stalk was NCS-465 $(1.6 \mathrm{~cm})$, whereas maximum average width of stalk was observed in Portbella $(2.5 \mathrm{~cm})$ followed by A-15 $(2.3 \mathrm{~cm})$, U-3 $(2.0 \mathrm{~cm})$, Delta $(1.6 \mathrm{~cm})$, NCS-459 $(1.4$ $\mathrm{cm})$ however minimum width of stalk was observed in NCS-465 $(1.2 \mathrm{~cm})$. Maximum 
average width of cap was observed in Portbella $(4.8 \mathrm{~cm})$ followed by A-15 $(4.5 \mathrm{~cm})$, U-3 $(3.8 \mathrm{~cm})$, Delta $(3.6 \mathrm{~cm})$, NCS-459 $(3.2$ $\mathrm{cm})$, and NCS-465 $(3.0 \mathrm{~cm})$ moreover average maximum length of cap was observed in Portbella $(5.0 \mathrm{~cm})$ followed by A-15 $(4.7$ $\mathrm{cm}), \mathrm{U}-3(4.0 \mathrm{~cm})$, Delta $(3.9 \mathrm{~cm})$, NCS -459 $(3.5 \mathrm{~cm})$, and minimum were taken in NCS$465(3.2 \mathrm{~cm})$.

Table.1 Growth behavior of the different strains of Agaricus bisporus (Lange) Sing

Number of days

\begin{tabular}{lllllll}
\hline Strain & Spawn run & Case run & $\begin{array}{l}\text { Pinhead } \\
\text { formation* }\end{array}$ & $\mathbf{I}^{\text {st }}$ harvest* & $\begin{array}{l}\mathbf{I I}^{\text {nd }} \\
\text { harvest* }\end{array}$ & $\begin{array}{l}\text { III }^{\text {rd }} \\
\text { harvest* }\end{array}$ \\
\hline A-15 & 17 & 16 & 19 & 21 & 32 & 43 \\
Delta & 16 & 15 & 17 & 20 & 30 & 41 \\
U-3 & 15 & 13 & 15 & 18 & 28 & 37 \\
NCS-459 & 17 & 18 & 21 & 24 & 33 & 41 \\
NCS-465 & 14 & 14 & 17 & 20 & 30 & 39 \\
Portbella & 15 & 15 & 17 & 20 & 31 & 41 \\
& & & & & & \\
\hline SEm \pm & 0.618 & 0.839 & 0.831 & 0.831 & 0.853 & 0.803 \\
CD $(5 \%)$ & 1.836 & 2.494 & 2.469 & 2.469 & 2.537 & 2.387 \\
\hline
\end{tabular}

*Average of four replications

Table.2 Yield performance of different strains of Agaricus bisporus (Lange) Sing

\begin{tabular}{llll} 
Strain & $\begin{array}{l}\text { Mushroom yield* } \\
\text { (gm/8 kg of compost) }\end{array}$ & $\begin{array}{l}\text { Number of } \\
\text { fruiting body } \\
\text { /8 kg of } \\
\text { compost* }\end{array}$ & $\begin{array}{l}\text { Average } \\
\text { individual fruit } \\
\text { body weight* } \\
\text { (gm) }\end{array}$ \\
\hline A-15 & 1160.00 & 120 & 9.66 \\
Delta & 1140.00 & 122 & 9.34 \\
U-3 & 1246.40 & 115 & 10.83 \\
NCS-459 & 1216.00 & 120 & 10.13 \\
NCS-465 & 1184.00 & 128 & 9.25 \\
Portbella & 1150.00 & 96 & 12.00 \\
\hline SEm \pm & 21.860 & 6.110 & 0.415 \\
CD $(5 \%)$ & 64.950 & 18.153 & 1.237 \\
\hline
\end{tabular}

* Average of four replications. 
Table.3 Morphological characterstics of different strains of Agaricus bisporus (Lange) Sing

\begin{tabular}{|c|c|c|c|c|}
\hline \multicolumn{4}{|c|}{ Average } & \multirow[b]{2}{*}{$\begin{array}{l}\text { Length of } \\
\text { mushroom } \\
\text { cap }(\mathrm{cm})\end{array}$} \\
\hline Strain & $\begin{array}{l}\text { Length of stalk } \\
\text { (cm) }\end{array}$ & $\begin{array}{l}\text { Width of stalk } \\
\quad(\mathrm{cm})\end{array}$ & $\begin{array}{l}\text { Width of } \\
\text { mushroom } \\
\text { cap }(\mathrm{cm})\end{array}$ & \\
\hline A-15 & 3.2 & 2.3 & 4.5 & 4.7 \\
\hline Delta & 2.4 & 1.6 & 3.6 & 3.9 \\
\hline U-3 & 2.8 & 2.0 & 3.8 & 4.0 \\
\hline NCS-459 & 2.2 & 1.4 & 3.2 & 3.5 \\
\hline NCS-465 & 1.6 & 1.2 & 3.0 & 3.0 \\
\hline Portbella & 3.5 & 2.5 & 4.8 & 5.0 \\
\hline SEm \pm & 0.400 & 0.175 & 0.404 & 0.386 \\
\hline $\mathrm{CD}(5 \%)$ & 1.189 & 0.521 & 1.203 & 1.148 \\
\hline
\end{tabular}

* Average of four replications.

Thus, it can be conclude from above results that maximum average length, width of stalk and average width, length of cap was observed in Portbella and minimum was observed in NCS-465. This results showed that confirmative results with finding of Prakasam et al., (2008) reported that Cultural and morphological variations of seven strains of Agaricus bisporus (CM-1, CM-5, CM- 10, Delta, S-130, S-140 \& X-13) and a strain (NCB-13) of Agaricus bitorquis were studied on the basis of growth on MEA medium, synthetic compost and casing soil, and different characters of their fruiting body. Strain S-130 showed maximum growth on MEA medium, compost and casing soil whereas NCB-13 produced higher fruit body weight and stipe width. Lesser stipe length and maximum pileus diameter were observed in strain Delta. Maximum pileus thickness was observed in CM-5.

\section{Acknowledgements}

The authors are thankful to the Department of Plant Pathology, RCA, Udaipur, for providing necessary facilities in carrying out the present investigation.

\section{References}

Chang, S.T. and P.G. Miles. 2004. Mushrooms: Cultivation, nutritional value, medicinal effect, and environmental impact, 2nd ed. CRC Press, Boca Raton, FL

Garcha, H.S. and U. Kiran. 1981. Studies on mushroom composts under tropical conditions. Mush. Sci., 11: 219-233. 
Kushwaha, K.P.S., R.C. Verma and R.P. Singh. 2006. Yield performance of different strains of Agaricus bisporus. Int. J. Pl. Sci. (Muzaffarnagar)., 1(2): 264-265.

Pal, D.P., A.K. Deo, B. Das, C.S. Shukla, A.K. Mohanty, and M.K. Tripathi. 2006. Evaluation of different strains of white button mushroom. J. Soi. Cr., 16(2): 291-294.

Prakasam, V. and R.P. Singh. 2008. Cultural and morphological characterization of Agaricus bisporus strains. Ann. Pl. Prot. Sci., 16: 454-57.

Singh, M., B. Vijay, S. Kamal, and G.C. Wakcaure. 2011. MushroomsCultivation, Marketing and Consumption. Directorate of Mushroom Research, Solan, pp. 266.

Vijay, B. and Y. Gupta. 1995. Production technology of Agaricus bisporus. Adv. Horti., 13: 64-95.

\section{How to cite this article:}

Suresh Kumar, Anila Doshi, Dinesh Kumar and Kuldeep Singh. 2017. Evaluation of High Yielding Strains of Agaricus bisporus (Lange) Sing. Int.J.Curr.Microbiol.App.Sci. 6(5): 16971702. doi: https://doi.org/10.20546/ijcmas.2017.605.184 